\title{
USE OF MIXTURE DESIGN TO IMPROVE A TROPICAL MIXED FRUIT NECTAR
}

\author{
PAULO HENRIQUE MACHADO DE SOUSA* \\ AFONSO MOTA RAMOS** \\ EDY SOUZA DE BRITO*** \\ GERALDO ARRAES MAIA**** \\ HENRIETTE MONTEIRO CORDEIRO DE AZEREDO***** \\ GIOVANA MATIAS DO PRADO****** \\ MARIA LEÔNIA DA COSTA GONZAGA******
}

\begin{abstract}
This study aimed to develop beverages of mixed nectars of tropical fruits and to determine the best accepted formulation. The puree blend contents were: cashew apple (12.25-21.00 $\left.100 \mathrm{~g}^{-1}\right)$; acerola

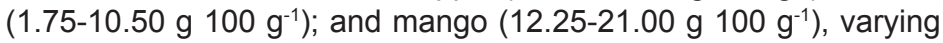
according to a mixture design. The evaluated responses were based on physicochemical, chemical and sensorial determinations. The models for antioxidant activity, overall acceptance, ascorbic acid content, phenolic content and viscosity were statistically significant $(\mathrm{P} \leq 0.05)$. The formulation with $12.25 \mathrm{~g}$ of cashew apple puree $100 \mathrm{~g}^{-1}, 21.00 \mathrm{~g}$ of mango puree $100 \mathrm{~g}^{-1}$ and $1.75 \mathrm{~g}$ of acerola puree $100 \mathrm{~g}^{-1}$ was the best accepted by the tasters. Mango and cashew apple purees must be present in a greater proportion in the mixture, since they have high flavour acceptance. The antioxidant activity of mixed nectars was most increased by acerola, followed by cashew apple. A high correlation was observed between antioxidant activity and acerola puree content and there was also a high correlation between antioxidant activity and both ascorbic acid and total phenolic contents.
\end{abstract}

KEY-WORDS: TROPICAL FRUITS; SENSORY EVALUATION; ANTIOXIDANT ACTIVITY.

* Doutor em Ciência e Tecnologia de Alimentos, Professor, Instituto de Cultura e Arte, Universidade Federal do Ceará (UFC) Fortaleza, CE (e-mail: phenriquemachado@gmail.com).

** Doutor em Ciência e Tecnologia de Alimentos, Professor, Departamento de Tecnologia de Alimentos, Universidade Federal de Viçosa (UFV), Viçosa, MG (e-mail: amramos@ufv.br).

*** Doutor em Tecnologia de Alimentos, Pesquisador, Embrapa Agroindústria Tropical, Fortaleza, CE (e-mail: edy@cnpat. embrapa.br).

**** PhD em Ciência dos Alimentos, Professor Emérito, Departamento de Tecnologia de Alimentos, UFC, Fortaleza, CE (e-mail: gamaia@netbandalarga.com.br).

**** Doutora em Tecnologia de Alimentos, Pesquisadora, Embrapa Agroindústria Tropical, Fortaleza, CE (e-mail: ette@ cnpat.embrapa.br).

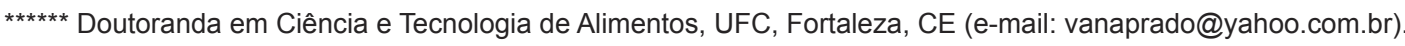

****** Doutora em Química Inorgânica, Pesquisadora, Departamento de Tecnologia de Alimentos, UFC, Fortaleza, CE (e-mail: leonia_gonzaga@yahoo.com.br). 


\section{INTRODUCTION}

There is a growing market for beverages made from mixed fruits, especially tropical fruits. Such products may be carbonated or not, with a varying content of fruit puree. Mixed fruit formulations have many advantages, such as the possibility of combining different flavours, as well as nutritional and functional components, such as ascorbic acid, phenolic compounds and carotenoids.

Tropical fruits are widely accepted by consumers, and they are important sources of antioxidant compounds (REDDY, SREERAMULU \& RAGHUNATH, 2010). Acerola fruit (Malpighia emarginata D.C.) has very high ascorbic acid levels and is also rich in anthocyanins and carotenoids: antioxidant pigments whose combination is responsible for its red colour (LIMA et al., 2005; ROSSO and MERCADANTE, 2005). Mangoes contain considerable levels of phenolic compounds and carotenoids (LUXIMON-RAMMA, BAHORUN \& CROZIER, 2005). Cashew apple is a good source of ascorbic acid, carotenoids and phenolic compounds (KUBO et al., 2006). Cashew apple is mainly used as juice, but high astringency tends to impair its acceptance. The formulation of mixed fruits and nectars may be an efficient way of reducing the negative impact caused by cashew apple astringency. Mangoes have also been used as components of mixed nectars because of the high viscosity of their juice and their exotic and much appreciated flavour. In addition, mangoes are an important source of $\beta$-carotene, minerals and fibre (MOSTAFA, ABD-EL-HADY \& ASKAR, 1997). Some authors have mentioned the possibility of using acerola puree to increase the ascorbic acid contents of several juices and nectars (SOUSA et al., 2010; JAIN and KHURDIYA, 2004; MATSUURA et al., 2004; AKINWALE, 2000).

The emphasis on the antioxidant capacity of foods is supported by indications that oxidative stress (which occurs when the rate of formation of free radicals exceeds that of their inactivation) is an etiologic factor for several chronic diseases. In physiological conditions, the aggressor compounds are controlled by an integrated and harmonic action of enzymes that depends on antioxidant nutrients provided mainly by vegetable foods, such as vitamin $C$ and other bioactive compounds. The antioxidant action of polyphenols, the most important antioxidant group, is independent of the enzymatic system (ARAYA, CLAVIJO \& HERRERA, 2006). The ingestion of foods rich in antioxidant compounds, such as vitamins $C$ and $E$, carotenoids and phenolics, prevents the development of certain diseases and there is evidences which corroborates the hypothesis that dietetic antioxidants enhance the antioxidant defence system, decreasing oxidative damage (LE CORE et al., 2004).

The experimental design is the most important stage of experiments, since it makes an experiment capable of providing the exact desired information. Several designs can be used, such as complete or fractioned factorial designs, central composite designs and mixture designs. The mixture design is an important methodology for the development and optimisation of food formulations. The quality of a food product normally depends on the proportions of the single ingredients present in the formulations. Unlike classic factorial design methods, this method takes into consideration the interaction between the mixture components, which are also considered during planning and analysis of the results. The proportions of the several components of a mixture are not independent variables because the sum of the components is always $100 \%$ (DINGSTAD, WESTAD \& NAES, 2004; BJERKE, NAES \& ELLEKJAER, 2000). This technique, when combined with sensory analysis, is a relevant tool to design new food products and such a combination has been used in the optimisation of fruit juice and fruit juice blends (SOUSA et al., 2007; VIEIRA and SILVA, 2004).

This study aimed to develop formulations of mixed tropical fruit nectars enriched with ascorbic acid present in acerola puree, using a mixture design to determine the proportions of cashew apple, mango and acerola purees for the best accepted formulation, and to evaluate the antioxidant activity and its correlation with the bioactive compounds of these nectars. 


\section{MATERIAL AND METHODS}

\subsection{RAW MATERIAL}

Cashew apple, mango and acerola puree, freshly extracted and pasteurised by a local fruit juice industry (Ceará, Brazil) were used. The formulated blended juices were diluted in potable water and the total soluble solids were standardised with sucrose.

\subsection{FRUIT PUREE CHARACTERISATION}

The following determinations were performed on the purees out accordance with Instituto Adolfo Lutz (2008): pH, soluble solids (SS), titratable acidity (TA), SS/TA ratio and ascorbic acid contents.

\subsection{NECTAR FORMULATION AND EXPERIMENTAL DESIGN}

The formulations were composed of $35 \%$ puree blend and sucrose and potable water up to $11^{\circ}$ Brix. The proportions of cashew apple, acerola and mango puree in each treatment were defined according to a simplex mixture design, with 10 treatments (MYERS and MONTGOMERY, 2002) as shown in Table 1. Since the sum of the proportions of a mixture has to be $1.0(100 \mathrm{~g}$ $100 \mathrm{~g}^{-1}$ ), the values of the fruit puree contents (whose sum was $35 \mathrm{~g}$ of puree $100 \mathrm{~g}^{-1}$ ) were normalised to make the sum equal to 1.00 .

The puree proportion ranges were established by preliminary tests. Acerola puree was added in the lowest proportions, due to its limited sensory acceptance (MATSUURA et al., 2004). The fruit purees were added with water and sugar, and homogenised. Three replications were performed for each formulation. The nectar from each treatment was heated $\left(90^{\circ} \mathrm{C}, 60 \mathrm{~s}\right)$, hot-filled in $200 \mathrm{~mL}$ glass containers, closed with a plastic screw cap and cooled in running water. Samples from all the treatments were submitted to sensory evaluations, as well as physicochemical and chemical determinations.

\subsection{SENSORY EVALUATION}

Sensory acceptance tests were carried out according to Stone and Sidel (1993) in order to evaluate the acceptance of each formulation by potential consumers. Fifty-five non-trained tasters were enlisted. The tests were applied in individual booths equipped with daylight fluorescent lamps. The nectars were served monadically, under controlled conditions. All the tasters evaluated samples from all the treatments. The samples $(30 \mathrm{~mL})$ were served at normal consumption temperature $\left(10 \pm 1{ }^{\circ} \mathrm{C}\right)$, in glasses codified with random three digit numbers. The order of presentation was balanced according to the design proposed by Macfie et al. (1989). Global impression was evaluated by using a nine-category structured hedonic scale (PERYAM and PILGRIM, 1957). For data analysis, numerical values were associated to each category, from 1 ("disliked very much") to 9 ("liked very much").

\subsection{PHYSICOCHEMICAL DETERMINATIONS}

The chemical and physicochemical determinations were conducted at least in duplicates for each replication of the 10 treatments. The $\mathrm{pH}$ was determined by using a $\mathrm{pH}$ meter (Hanna Instruments, model HI 9321), periodically calibrated with buffered solutions (pH 4.0 and 7.0) (IAL, 2008). Soluble solids (SS) contents were determined by refractometry, by using a manual Atago refractometer model $\mathrm{N}-50 \mathrm{E}$, at room temperature; the results were expressed in ${ }^{\circ} \mathrm{Brix}$ (IAL, 2008). Titratable acidity (TA) was determined by titrimetry by using a $\mathrm{NaOH}$ solution $\left(0.1 \mathrm{~mol} \mathrm{~L}^{-1}\right)$, according 


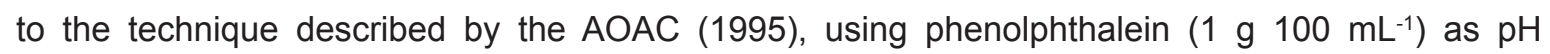
indicator; the results were expressed as $\mathrm{g}$ of citric acid $100 \mathrm{~mL}^{-1}$ of sample. The suspended insoluble solids content determination was conducted according to the International Federation of Fruit Juice Producers (IFFJP, 1991), using an Excelsa II, model 206MP centrifuge. A $50 \mathrm{~mL}$ sample was centrifuged at $370 \mathrm{~g}$ for $10 \mathrm{~min}$ and the suspended insoluble solids content was measured directly

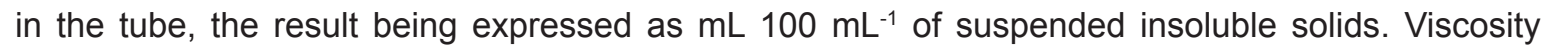
measurements were performed using a digital Brookfield rheometer (model DV-III+) coupled to a water circulation thermostatic bath (FANEM, model 111) at $25.0^{\circ} \mathrm{C} \pm 0.1{ }^{\circ} \mathrm{C}$, and equipped with a CP52 spindle, using $0.5 \mathrm{~mL}$ of sample, by applying a $0.5 \mathrm{rpm}$ cycle and a shear rate of $1 \mathrm{~s}^{-1}$ (FERRARI and ROCHA-FILHO, 2011).

\subsection{CHEMICAL DETERMINATIONS}

Total phenolics were determined according to the Folin-Ciocalteu method (ZIELINSKI and KOZLOWSKA, 2000). In a dark room, the samples ( $5 \mathrm{~mL}$ ) were dissolved in $40 \mathrm{~mL}$ of distilled water $(6: 4 \mathrm{v}: \mathrm{v})$ and placed in a water bath for $2 \mathrm{~h}$ at $85^{\circ} \mathrm{C}$ for the elimination of ascorbic acid, according to Georgé et al. (2005). After cooling, the samples were placed in a $100 \mathrm{~mL}$ volumetric flask and the volume was completed with distilled water. The extracts were filtered under reduced pressure through filter paper (Whatman No. 1). An aliquot of $5 \mathrm{~mL}$ of extracts was added to $15 \mathrm{~mL}$ distilled water, $5 \mathrm{~mL}$ of Folin-Denis reagent, and $10 \mathrm{~mL}$ of a saturated solution of sodium carbonate, completing the volume to $100 \mathrm{~mL}$ with distilled water. After standing for $30 \mathrm{~min}$ at room temperature, the absorbance was measured at $760 \mathrm{~nm}$ using a UV-vis spectrophotometer (Micronal, Model B582, São Paulo, Brazil). All determinations were made in triplicate and values were calculated from the calibration curves obtained with five concentrations of gallic acid. Linearity was obtained between 0 and $5 \mathrm{mg} \mathrm{mL}^{-1}$, corresponding to absorbance values between 0.0 and 0.5 . The total phenolics were expressed as milligram of gallic acid equivalents (GAE) $100 \mathrm{~g}^{-1}$ of fresh weight. The ascorbic acid (AA) content was determined by the 2,6-dichlorophenol-indophenol titration method, described in

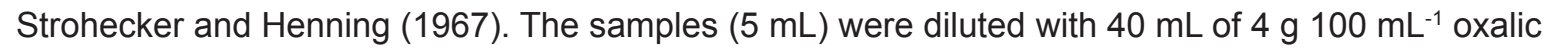
acid aqueous solution. The solution was titrated by adding the 2,6-dichlorophenol-indophenol solution until a distinct rose-pink colour persisted. Several precautions were taken in order to perform all the operations under reduced light and at $4{ }^{\circ} \mathrm{C}$. The L-ascorbic acid was used to prepare a standard solution $\left(0.5 \mathrm{mg} \mathrm{mL}^{-1}\right)$ and the ascorbic acid concentration was calculated by comparison with the

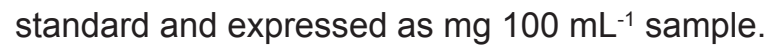

\subsection{ANTIOXIDANT ACTIVITY}

For the antioxidant activity determination, the nectars were homogenised in a blender and centrifuged at $15000 \mathrm{rpm}$ for $15 \mathrm{~min}$. The supernatant was collected, filtered and its antioxidant activity was determined through the 2,2'-azinobis(3-ethylbenzothiazoline-6-sulfonic acid) (ABTS) method of $\mathrm{Re}$ et al. (1999) modified by Almeida et al. (2011). The ABTS radical cation (ABTS $\cdot+$ ) was generated by the reaction of $5 \mathrm{~mL}$ of aqueous ABTS solution $(7 \mathrm{mM})$ and $88 \mu \mathrm{L}$ of $140 \mathrm{mM}$ (2.45 mM final concentration) of potassium persulfate solution. The mixture was held in the dark at $29^{\circ} \mathrm{C}$ for $14 \mathrm{~h}$ before use, and then it was diluted with ethanol to obtain an absorbance of $0.7 \pm 0.02$ units at $734 \mathrm{~nm}$ using a UV-vis spectrophotometer (Micronal, Model B582, São Paulo, Brazil). Fruit extracts $(30 \mu \mathrm{L})$ or reference substance (Trolox) were allowed to react with $3 \mathrm{~mL}$ of the resulting blue-green ABTS radical solution in dark conditions. The decrease of absorbance at $734 \mathrm{~nm}$ was measured at the endpoint of $6 \mathrm{~min}$. The standard curve was linear between 0-15 $\mu \mathrm{M}$ of Trolox $1 \mathrm{~mL}^{-1}$ (final concentration). The results were thus expressed as Trolox Equivalent Antioxidant Capacity (TEAC). The activity of extracts was estimated at a minimum of three different concentrations. All tests were performed in triplicate. 


\subsection{STATISTICAL ANALYSIS}

The mathematical description of the mixture modelling was performed by using the Statistica software, version 5.0 (STATSOFT, 1995). The models obtained for the experimental responses were evaluated in terms of their significance $(P \leq 0.05)$ and determination coefficients $\left(R^{2}\right)$. Correlations between antioxidant capacity and phenolics, carotenoids and ascorbic acid contents were determined using Pearson's Correlation Coefficient Test (ALMEIDA et al., 2011).

\section{RESULTS AND DISCUSSION}

The results of the physicochemical evaluation of the fruit puree used as raw materials are shown in Table 1. The $\mathrm{pH}, \mathrm{SS}, \mathrm{TA}$ and SS/TA ratio values from the fruit purees were consistent with those observed by other authors for acerola (VENDRAMINI and TRUGO, 2005), mango (AKINWALE, 2000; MOSTAFA, ABD-EL-HADY \& ASKAR, 1997) and cashew apple (AKINWALE, 2000).

\section{TABLE 1 - PHYSICOCHEMICAL CHARACTERISATION OF THE FRUIT PUREES USED IN THE EXPERIMENT}

\begin{tabular}{llll}
\hline DETERMINATIONS & \multicolumn{3}{c}{ Purees } \\
\cline { 2 - 4 } & Cashew apple & Mango & Acerola \\
\hline $\mathrm{pH}$ & 3.92 & 3.55 & 3.54 \\
Soluble solids content (SS) ('Brix) & 16.0 & 14.0 & 5.5 \\
Titratable acidity (TA) (g of citric acid $\left.100 \mathrm{~mL}^{-1}\right)$ & 0.8 & 0.9 & 0.9 \\
SS/TA ratio & 12.3 & 10.5 & 3.9 \\
Ascorbic acid (mg of ascorbic acid $\left.100 \mathrm{~mL}^{-1}\right)$ & 296.4 & 49.0 & 688.1 \\
\hline
\end{tabular}

The acerola puree contained the highest ascorbic acid content $(688.1 \mathrm{mg}$ $\left.100 \mathrm{~mL}^{-1}\right)$, followed by the cashew apple (294.4 mg $\left.100 \mathrm{~mL}^{-1}\right)$ and mango $\left(49.0 \mathrm{mg} 100 \mathrm{~mL}^{-1}\right)$ purees. The cashew apple puree presented higher ascorbic acid levels than those reported by Assunção and Mercadante (2005). The ascorbic acid content for mango was within the range reported previously by Akinwale (2000). On the other hand, the ascorbic acid levels of the acerola puree were much lower than those reported by Assis, Lima and Oliveira (2001).

The models of antioxidant activity, overall acceptance, ascorbic acid, phenolics and viscosity were statistically significant $(P \leq 0.05)$. The total acidity, $\mathrm{pH}$, suspended insoluble solids and carotenoids were not significant $(P>0.05)$. The contour graphics shown in Figure 1 represent the surface response generated by the coefficients of equations in a diagram of triangular coordinates. The experimental responses of each mixture design treatment are shown in Table 2. In some cases, the linear model was the only one with a significant $F$ value $(p \leq 0.05)$; in others, the quadratic or special cubic models were found to be more adequate to represent attribute variations.

Analysis of Figure 1 indicates that overall acceptance was greater in mixtures with higher proportions of mango puree, followed by cashew apple puree, while the acerola puree received the lowest acceptance grades. However, the least accepted formulation still presented a good acceptance level. Only formulation 3, which had the highest acerola proportion, presented a hedonic value below 7 ("liked moderately"). The other formulations presented average hedonic values ranging from 7.0 to 7.7 (Table 2). Although the high ascorbic acid content in acerola puree is an advantage in terms of antioxidant properties, its presence in higher concentrations tended to impair the acceptance of 
the nectar. This observation is in accordance with results reported by Matsuura et al. (2004). The higher acceptance of blends with higher mango puree proportions were in agreement with results obtained by Mostafa, Abd-El-Hady and Askar (1997), who observed that the mixture with mango puree enhanced the acceptance of a papaya juice.

\section{TABLE 2 - PROPORTIONS OF THE FRUIT PUREE COMPONENTS FOR EACH TREATMENT AND MEANS OF THE SENSORY AND PHYSICOCHEMICAL DETERMINATIONS OF THE MIXED NECTARS OBTAINED FROM THE MIXTURE DESIGN}

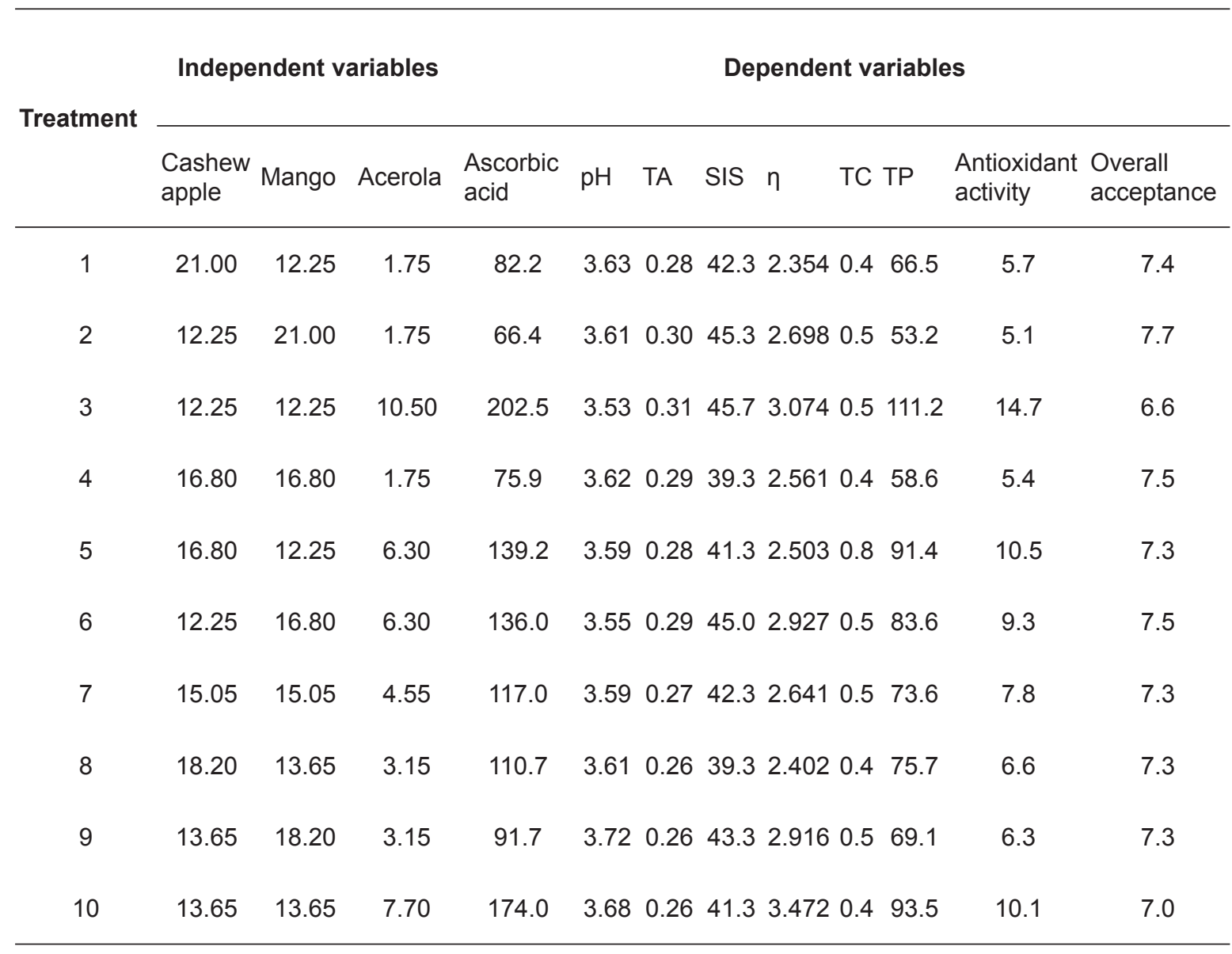

$\mathrm{TA}=$ titrable acidity ( $\mathrm{g}$ of citric acid $\left.100 \mathrm{~mL}^{-1}\right) ; \mathrm{SIS}=$ suspended insoluble solid $(\%) ; \eta=$ viscosity $(\mathrm{mPa}$ s); TC = total carotenoids

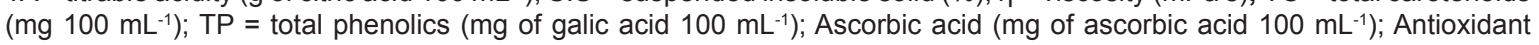
activity $\left(\mu \mathrm{M}\right.$ trolox $\left.\mathrm{mL}^{-1}\right)$.

Acidity and $\mathrm{pH}$ varied little among the formulations, which was attributed to the similar $\mathrm{pH}$ and acidity values of the purees. However, a small acidity increase and $\mathrm{pH}$ reduction was observed and this was attributed to the acerola puree. Such tendencies became very small due to the low proportion of acerola puree used in the formulations. The acidity and $\mathrm{pH}$ values were in accordance with results reported by other authors (MATSUURA et al., 2004; AKINWALE, 2000). The suspended insoluble solid contents presented little variation among the formulations, ranging from $39.3 \mathrm{~mL} 100 \mathrm{~mL}^{-1}$ to

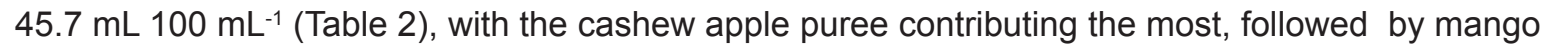
puree. The acerola puree contributed most to increases in the viscosity of the mixtures, followed by the mango puree (Figure 1).

The acerola puree increased the content of total phenolics, despite the small amount of puree used in the formulations. The total phenolic contents varied from 53.25 to $111.20 \mathrm{mg}$ of EAG $100 \mathrm{~mL}^{-1}$ of nectar and were higher when more acerola puree was used (Table 1; Figure 1). 


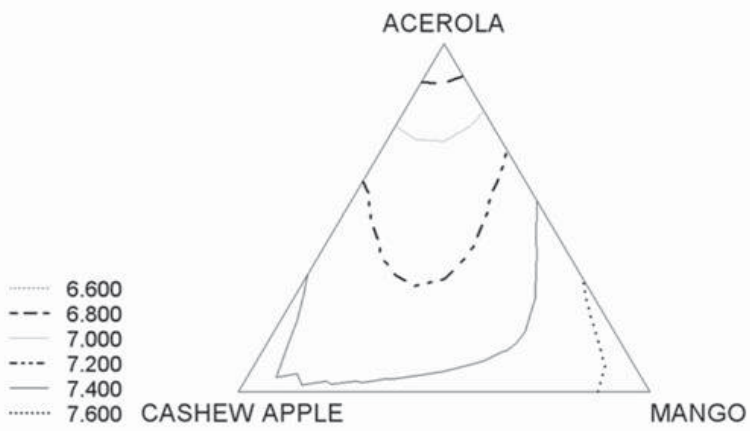

Overall acceptance $=2.44 \mathrm{C}+2.38 \mathrm{M}-65.96 \mathrm{~A}+19.81 . \mathrm{C} . \mathrm{M}+187.71 \mathrm{CA}+189.46 \mathrm{MA}-481.13 \mathrm{CMA}$ $\mathrm{R}^{2}=0.951$
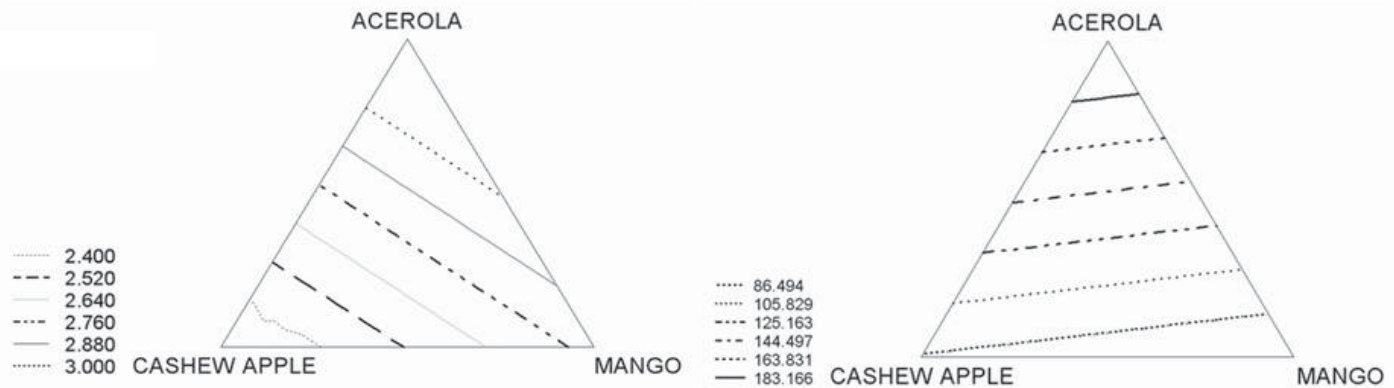

Viscosity $=1.30 \mathrm{C}+3.47 \mathrm{M}+5.14 \mathrm{~A}$ $\mathrm{R}^{2}=0.645$

Ascorbic acid $=85.09 \mathrm{C}+67.16 \mathrm{M}+206.43 \mathrm{~A}$ $\mathrm{R}^{2}=0.984$
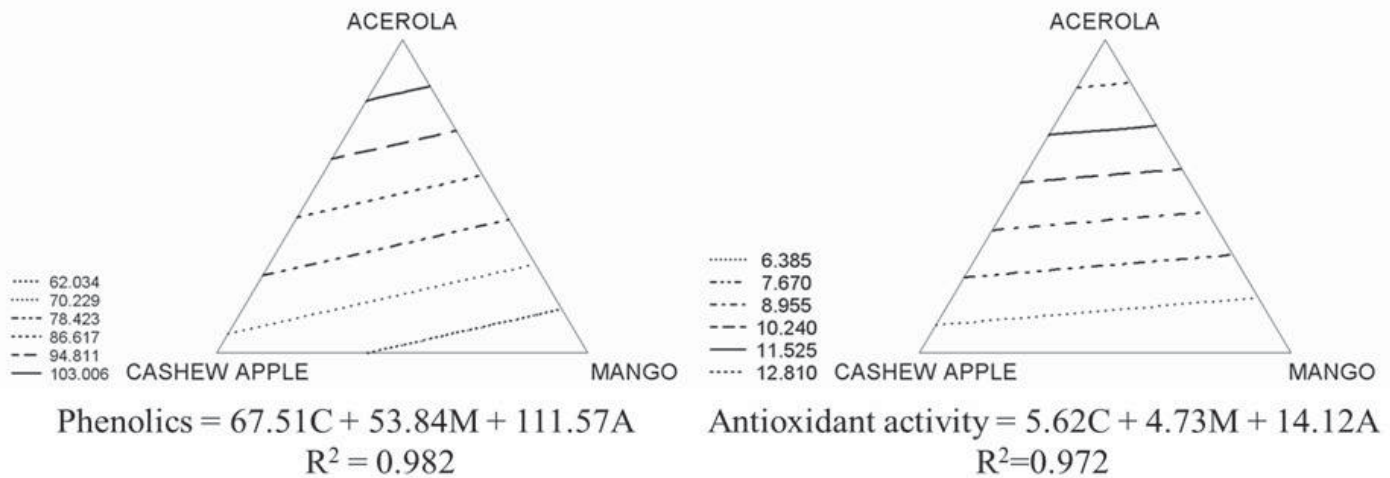

Phenolics $=67.51 \mathrm{C}+53.84 \mathrm{M}+111.57 \mathrm{~A}$ $\mathrm{R}^{2}=0.982$

$$
\mathrm{R}^{2}=0.972
$$

\section{FIGURE 1 - CONTOUR CURVES OF THE SPECIAL CUBIC MODEL FOR OVERALL ACCEPTANCE (1: Disliked very much to 9: Liked very much) AND THE LINEAR MODELS FOR VISCOSITY (MPA.S), PHENOLICS (mg galic acid.100 $\mathrm{mL}^{-1}$ ), ASCORBIC ACID (mg of ascorbic.100 $\mathrm{g}^{-1}$ ) AND ACTIVITY ANTIOXIDANT $\left(\mu \mathrm{M}\right.$ trolox. $\left.\mathrm{mL}^{-1}\right)(\mathrm{A}=\mathrm{ACEROLA}$ PROPORTION; $\mathrm{B}=$ MANGO PROPORTION; C = CASHEW APPLE PROPORTION)}

Acerola puree was the component that most contributed to enhance the ascorbic acid content, followed by cashew apple puree. The ascorbic acid content varied considerably (66.5-202.5 mg of ascorbic acid $100 \mathrm{~mL}^{-1}$ ) between the formulations (Table 1; Figure 1). Even so, a daily portion of $200 \mathrm{~mL}$ (volume of the package used) of the formulation presenting the lowest content of ascorbic acid would provide $295 \%$ of the recommended daily intake (RDI) of this vitamin, i.e., $45 \mathrm{mg} \mathrm{day}^{-1}$ (FAO/WHO, 2001). Matsuura and Rolim (2000) enhanced ascorbic acid levels of pineapple juices by mixing them with acerola juice, with little or no impairment of the sensory

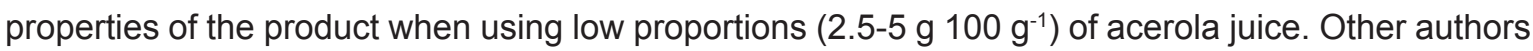
utilised cashew apple juice to enhance ascorbic acid levels of mixed fruits (AKINWALE, 2000; INYANG and ABAH, 1997). It is evident from the ascorbic acid contents of the formulations that 
acerola and cashew apple purees can be used to fortify the nutritional quality of fruit blends that are low in ascorbic acid.

The antioxidant activity varied considerably (5.1-14.7 $\mu \mathrm{M}$ trolox $\mathrm{mL}^{-1}$ ) between the formulations and was better in the mixtures with higher proportions of acerola puree, followed by cashew apple and mango (Table 1; Figure 1). A great correlation was observed between the antioxidant activity and proportion of acerola puree; the nectars with greater amounts of ascorbic acid were responsible for the increase in the antioxidant activity.

The Pearson correlation was performed regarding antioxidant activity and the other variables studied. The antioxidant activity (TEAC) showed a significant correlation with total phenolic $(r=0.934$; $P \leq 0.05)$ and ascorbic acid ( $r=0.938 ; P \leq 0.05)$ content, at a $5 \%$ level of probability, presenting a highly positive correlation; while for the carotenoid content the correlation was not significant $(r=0.127 ; P>0.05)$. Similar results were observed by Kuskoski et al. (2005), who detected a positive correlation between phenolic compounds and the antioxidant activity in fruit purees, as well as by Gardner et al. (2000), who observed that antioxidant activity was well correlated between total phenolic and ascorbic acid contents, and not with carotenoids, in several fruit juices. However, Hassimoto, Genovese and Lajolo (2005) did not find a correlation between vitamin C content and the antioxidant activity in fruits.

\section{CONCLUSION}

Mango and cashew apple juices must be present in a greater proportion in the mixture, since they have high flavour acceptance. On the other hand, the presence of acerola puree, even in a smaller proportion, contributes to increase ascorbic acid content in the mixture. The formulation with $21.00 \mathrm{~g}$ of acerola puree $100 \mathrm{~g}^{-1}, 12.25 \mathrm{~g}$ of cashew apple puree $100 \mathrm{~g}^{-1}$ and $1.75 \mathrm{~g}$ of acerola puree $100 \mathrm{~g}^{-1}$ received the best acceptance.

Higher proportions of acerola in the mixed fruit nectar contributed to increase the antioxidant activity, probably due to the high amounts of ascorbic acid and total phenolics in these formulations. The formulation with $12.25 \mathrm{~g}$ of cashew apple puree $100 \mathrm{~g}^{-1}, 12.25 \mathrm{~g}$ of mango puree $100 \mathrm{~g}^{-1}$, and $10.50 \mathrm{~g}$ of acerola puree $100 \mathrm{~g}^{-1}$ has the highest antioxidant activity.

\section{RESUMO}

\section{USO DE DELINEAMENTO DE MISTURAS PARA MELHORAR NÉCTAR MISTO DE FRUTAS TROPICAIS}

Este trabalho objetivou desenvolver néctares mistos de frutas tropicais e determinar a formulação mais aceita.

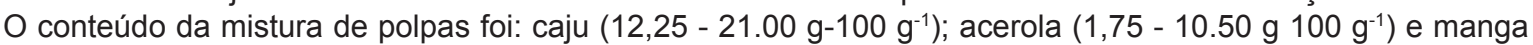
(12,25 - $\left.21.00 \mathrm{~g}-100 \mathrm{~g}^{-1}\right)$, variando de acordo com delineamento de mistura. As respostas avaliadas basearamse em determinações químicas, físico-químicas e sensoriais. Os modelos para a atividade antioxidante, a aceitação global, o teor de ácido ascórbico, fenólicos e viscosidade foram estatisticamente significativos $(\mathrm{P} \leq 0,05)$. A formulação com $12.25 \mathrm{~g}$ de polpa de caju.100 $\mathrm{g}^{-1}, 21.00 \mathrm{~g}$ de polpa de manga. $100 \mathrm{~g}^{-1} \mathrm{e} 1,75 \mathrm{~g}$ de polpa de acerola $100 \mathrm{~g}^{-1}$ obteve maior aceitação dos julgadores. Polpas de manga e caju devem estar presentes em maior proporção na mistura, devido a elevada aceitação do seu sabor. Deve-se o incremento da atividade antioxidante dos néctares mistos à contribuição da polpa de acerola, seguida pela de caju. Observou-se elevada correlação entre a atividade antioxidante e a proporção de polpa de acerola, e também alta correlação entre a atividade antioxidante e os conteúdos de ácido ascórbico e fenólicos totais.

PALAVRAS-CHAVE: FRUTAS TROPICAIS; AVALIAÇÃO SENSORIAL; ATIVIDADE ANTIOXIDANTE.

\section{REFERENCES}

1 AKINWALE, T.O. Cashew apple juice: its use in fortifying the nutritional quality of some tropical fruits. European Food Research and Technology, v.211, n.3, p.205-207, 2000. 
2 ALMEIDA, M.M.B.; SOUSA, P.H.M.; ARRIAGA, A.M.C.; PRADO, G.M.; MAGALHÃES, C.E. de C.; MAIA, G.A.; LEMOS, T.L.G. Bioactive compounds and antioxidant activity of fresh exotic fruits from northeastern Brazil. Food Research International, v.44, n.7, p.2155-2159, 2011.

3 Association of Official Analytical Chemists (AOAC). Official methods of analysis of the AOAC International (AOAC). $16^{\text {th }}$ ed. Virginia, 1995. $1141 \mathrm{p}$.

4 ARAYA, H.L.; CLAVIJO, C.R.; HERRERA, H. Capacidad antioxidante de frutas y verduras cultivados en Chile. Archives Latinoamericano de Nutrición, v.56, n.4, p.361-365, 2006.

5 ASSIS, S.A.; LIMA, D.C.; OLIVEIRA, O.M.M.F. Activity of pectinmethylesterase, pectin content and vitamin C in acerola fruit at various stages of fruit development. Food Chemistry, v.74, n.2, p.133-137, 2001.

6 ASSUNÇÃO, R.B.; MERCADANTE, A.Z. Carotenoids and ascorbic acid composition from commercial products of cashew apple (Anacardium occidentale L.). Journal of Food Composition and Analysis, v.16, n.6, p.647-657, 2005.

7 BJERKE, F.; NAES, T.; ELLEKJAER, M.R. An application of projection design in product development. Chemometrics and Intelligent Laboratory Systems, v.51, n.1, p.23-36, 2000.

8 DINGSTAD, G.I.; WESTAD, F.; NAES, T. Three case studies illustrating the properties of ordinary and partial least square regression in different mixture models. Chemometrics and Intelligent Laboratory Systems, v.71, n.1, p.33-45, 2004.

9 FERRARI, M.; ROCHA-FILHO, P.A. Multiple emulsions containing amazon oil: açaí oil (Euterpe oleracea). Revista Brasileira de Farmacognosia, Curitiba, v.21, n.4, p.737-743, ago. 2011.

10 Food and Agriculture Organization of the United Nations/ World Health Organization (FAO/WHO). Human vitamin and mineral requirements. Bangkok, 2001. 290 p. (Report 7ª Joint FAO/OMS Expert Consultation).

11 GARDNER, P.T.; WHITE, T.A.C.; MCPHAIL, D.B.; DUTHIE, G.G. The relative contributions of vitamin C, carotenoids and phenolics to the antioxidant potential of fruit juices. Food Chemistry, v.68, n.4, p.471-474, 2000.

12 GEORGÉ, S.; BRAT, P.; ALTER, P.; AMIOT, M.J. Rapid determination of polyphenols and vitamin C in plant-derived products. Journal of Agriculture and Food Chemistry, v.53, n.5, p.1370-1373, 2005.

13 HASSIMOTTO, N.M.A.; GENOVESE, M.I.S.; LAJOLO, F.M. Antioxidant activity of dietary fruits, vegetables, and commercial frozen fruit pulps. Journal of Agriculture and Food Chemistry, v.53, n.8, p.2928-2935. 2005.

14 Instituto Adolfo Lutz (IAL). Métodos físico-químicos para análise de alimentos. São Paulo, 2008. p. 1020.

15 International Federation of Fruit Juice Producers (IFFJP). Determination of centrifugable pulp. In: IFFJP analysis. Zug, Swizerland, 1991. 2 p.

16 INYANG, E.U.; ABAH, U.J. Chemical composition and organoleptic evaluation of juice from steamed cashew apple blended with orange juice. Plant Foods for Human Nutrition, v.50, n.4, p.295-300, 1997.

17 JAIN, S.K.; KHURDIYA, D.S. Vitamin C enrichment of fruit juice based ready-to-serve beverages through blending of Indian gooseberry (Emblica officinalis Gaertn.) juice. Plant Foods for Human Nutrition, v.59, n.2, p.63-66, 2004.

18 KUBO, I.; MASUOKA, N.; HA, T.J.; TSUJIMOTO, K. Antioxidant activity of anacardic acids. Food Chemistry, v.99, n.3, p.555-562, 2006.

19 KUSKOSKI, E. M.; ASUERO, A.G.; TRONCOSO, A.M.; MANCINI-FILHO, J.; FETT, R. Aplicación de diversos métodos químicos para determinar actividad antioxidante en pulpa de frutos. Ciência e Tecnologia de Alimentos, v.25, n.4, p.726-732, 2005

20 LE CORE, L.; FUSTIER, P.; CHALABI, N.; BIGNON, Y.J.; BERNARD-GALLON, D. Effects of resveratrol on the expression of a panel of genes interacting with the BRCA1 oncosuppressor in human breast cell lines. Clinica Chimica Acta, v.344, n.1-2, p.115-121, 2004.

21 LIMA, V.L.A.G.; MELO, E.A.; MACIEL, M.I.S.; PRAZERES, F.G.; MUSSER, R.S.; LIMA, D.E.S. Total phenolic and carotenoid contents in acerola genotypes harvested at three ripening stages. Food Chemistry, v.90, n.4, p.565-568, 2005.

22 LUXIMON-RAMMA, A.; BAHORUN, T.; CROZIER, A. Antioxidant actions and phenolic and vitamin C contents of common Mauritian exotic fruits. Journal of the Science of Food and Agriculture, v.83, p.496-502, 2003.

23 MAcFIE, H.J.; BRATCHELL, N.; GREENHOFF, K.; VALLIS, I.V. Designs to balance the effect of order of presentation and first-order carry-over effects in hall tests. Journal of Sensorial Studies, v.4, n.2, p.129-148, 1989.

24 MATSUURA, F.C.A.U.; ROLIM, R.B. Avaliação da adição de suco de acerola em suco de abacaxi visando à produção de um "blend" com alto teor de vitamina C. Revista Brasileira de Fruticultura, v.24, n.1, p.138-141, 2002. 
25 MATSUURA, F.C.A.U.; FOLEGATTI, M.I.S.; CARDOSO, R.L.; FERREIRA, D.C. Sensory acceptance of mixed nectar of papaya, passion fruit and acerola. Scientia Agricola, v.61, n.6, p.604-608, 2004.

26 MOSTAFA, G.A.; ABD-EL-HADY, E.A.; ASKAR, A. Preparation of papaya and mango nectar blends. Fruit Processing, v.7, n.5, p.180-185, 1997.

27 MYERS, R.H.; MONTGOMERY, D.C. Response surface methodology: process and product optimization using designed experiments. New York: Wiley, 2002. 824 p.

28 PERYAM, D.R.; PILGRIM, P.J. Hedonic scale method for measuring food preferences. Food Technology, v.11, n.9, p.9$14,1957$.

29 RE, R.; PELLEGRINI, A.P.; PANNALA, A.; YANG, M.; RICE-EVANS, C. Antioxidant activity applying an improved ABTS radical cation decolorization assay. Free Radical Biology \& Medicine, v.26, n.9-10, p.1231-1237, 1999.

30 REDDY, C.V.K.; SREERAMULU, D.; RAGHUNATH, M. Antioxidant activity of fresh and dry fruits commonly consumed in India. Food Research International, v.43, n.1, p.285-288, 2010.

31 ROSSO, V.V.; MERCADANTE, A.Z. Carotenoid composition of two Brazilian genotypes of acerola (Malpighia punicifolia L.) from two harvests. Food Research International, v.38, n.8-9, p.1073-1077, 2005.

32 SOUSA, P.H.M.; MAIA, G.A.; AZEREDO, H.M.C.; RAMOS, A.M.; FIGUEIREDO, R.W. Storage stability of a tropical fruit (cashew apple, acerola, papaya, guava and passion fruit) mixed nectar added caffeine. International Journal of Food Science \& Technology, v.45, n.10, p.2162-2166, 2010.

33 SOUSA, P.H.M.; MAIA, G.A.; AZEREDO, H.M.C.; SOUSA FILHO, M.S.M.; GARRUTI, D.S.; FREITAS, C.A.S. Mixed tropical fruit nectars with added energy components. International Journal of Food Science and Technology, v.42, n.11, p.1290-1296, 2007.

34 STATSOFT Inc. Statistics for Windows. [Computer program manual]. Tulsa, 1995.

35 STONE, H.; SIDEL, J.L. Sensory evaluation practices. New York: Academic Press, 1993. 338 p.

36 STROHECKER, R.; HENNING, H.M. Analisis de vitaminas: métodos comprobados. Madrid: Paz Montalvo, 1967. 428 p.

37 VENDRAMINI, A.L.; TRUGO, L.C. Phenolic compounds in acerola fruit (Malpighia punicifolia L.). Journal of the Brazilian Chemical Society, v.15, n.5, p.664-668, 2004.

38 VIEIRA, M.C.; SILVA, C.L.M. Optimization of a cupuaçu (Theobroma grandiflorum) nectar formulation. Journal of Food Processing and Engineering, v.27, n.3, p.181-196, 2004.

39 ZIELINSKI, H.; KOZLOWSKA, H. Antioxidant activity and total phenolics in selected cereal grains and their different morphological fractions. Journal of Agriculture and Food Chemistry, v.48, n.6, p.2008-2016, 2000.

\section{ACKNOWLEDGMENTS}

The authors would like to thank the CNPq for granting a doctorate scholarship, research scholarship and for funding this project through the Universal Edital CNPq number 019/2004. 